\title{
Physiological and biochemical responses of strawberry crown and leaf tissues to freezing stress
}

\author{
Elnaz Zareei ${ }^{1}$, Farhad Karami ${ }^{2}$, Mansour Gholami ${ }^{3}$, Ahmad Ershadi $^{3}$, Saber Avestan² ${ }^{2}$ Rishi Aryall ${ }^{4}$, \\ Gholamreza Gohari ${ }^{5}$ and Muhammad Farooq ${ }^{6}$
}

\begin{abstract}
Background: In northern Iran and other cold regions, winter freezing injury and resultant yield instability are major limitations to strawberry production. However, there is scarcity of information on the physiological and biochemical responses of strawberry cultivars to freezing stress. This study aimed to investigate the physiological and biochemical responses of strawberry cultivars (Tennessee Beauty, Blakemore, Kurdistan, Queen Elisa, Chandler, Krasnyy Bereg, and Yalova) to different freezing temperature treatments $\left(-5,-10,-15,-20\right.$, and $\left.-25^{\circ} \mathrm{C}\right)$ under controlled conditions.

Results: All measured physiological and biochemical features were significantly affected by the interaction effect between low temperatures and cultivars. Tennessee Beauty showed the highest RWC at $-25^{\circ} \mathrm{C}$. The highest Fv/ Fm was observed in Queen Elisa. Krasnyy Bereg had the least freezing injury (FI) in crown and leaf, while Yalova and Chandler showed the highest crown and leaf Fl, respectively. At -20 to $-25^{\circ} \mathrm{C}$, the highest carbohydrates contents of crown and leaf were noted in Blakemore and Krasnyy Bereg cultivars, respectively. The Yalova showed the highest protein content in both crown and leaf tissues at $-25^{\circ} \mathrm{C}$. The Tennessee Beauty and Blackmore cultivars showed the highest proline in crowns and leaves at $-15^{\circ} \mathrm{C}$, respectively. The highest ThioBarbituric Acid Reactive Substances (TBARS) contents in the crown and leaf were observed in Kurdistan and Queen Elisa, respectively. Queen Elisa and Krasnyy Bereg cultivars showed SOD and POD peaks in the crown at $-15^{\circ} \mathrm{C}$, respectively.

Conclusion: Freezing stress was characterized by decreased Fv/Fm and RWC, and increased FI, TBARS, total carbohydrates, total proteins, proline content, and antioxidant enzyme activity. The extent of changes in above mentioned traits was cultivar dependent. FI and TBARS were the best traits among destructive parameters for evaluating freezing tolerance. Moreover, maximum quantum yield of PSII (FV/Fm index), as non-destructive parameters, showed a significant efficiency in rapid assessment for screening of freezing tolerant strawberry cultivars. The cultivars Krasnyy Bereg, Queen Elisa, and Kurdistan were the most tolerant cultivars to freezing stress. These cultivars can be used as parents in breeding programs to develop new freezing tolerant cultivars.
\end{abstract}

Keywords: Freezing injury, TBARS, Strawberry, Fv/Fm, Cold acclimation, SOD, Abiotic stress

\footnotetext{
*Correspondence: f.karami@areeo.ac.ir

${ }^{2}$ Horticultural Research Department, Kurdistan Agricultural and Natural

Resources Research and Education Center, AREEO, Sanandaj, Iran

Full list of author information is available at the end of the article
}

\section{Background}

Freeze injury is one of the major environmental factors limiting the growth, development, and productivity of plants in temperate regions. The freeze injury depends on mechanisms linking cell dehydration and membrane disintegration via water crystallization during freezing [1-3]. However, the plant responses to freezing stress 
and associated tolerance mechanism involves different physiological, molecular, and metabolic alterations and adaptations $[4,5]$. These include the accumulation of soluble sugars, amino acids, cold-induced stress-related proteins..This expression of encoded genes to stabilize membranes against injury is an important component of this freezing tolerance mechanism [6, 7].

The plant's ability to tolerate low temperatures under natural conditions vary with plant species, cultivars, and tissues $[2,8,9]$. However, evaluation of freezing injury is significantly crucial for predicting plant winter survival, regrowth in the following spring. Such evaluation is also desired to recognize freezing-tolerant species and cultivars and to develop management strategies to improve plant performance under freezing stress. Strawberry (Fragaria $\times$ ananassa Duchesne) is a widely grown hybrid species of the genus Fragaria, collectively known as the strawberries. Strawberries are grown widely from mild maritime to severe temperate continental climates throughout the world. Despite its wider adaptability, the freezing stress is a major limiting factor in the production of strawberries particularly in the temperate regions. The changing climate is expected to increase in the extreme temperature events and associated spatiotemporal patterns [10]. These temperature extremes have a significant effect on the growth and productivity of strawberries [11, 12].

This is interesting to note that plant exposure to nonfreezing low temperatures can improve tolerance to freezing temperate plants through cold acclimation [13, 14]. Strawberry plants also acclimatize to freezing temperature conditions and can survive freezing temperatures by tolerating ice crystal formation in crown tissues. Water movement from within the cell to the intercellular spaces where ice crystals are formed $[15,16]$. This mechanism in association with osmotic adjustment help plants improve cold tolerance. In this regard, selection and use of cultivars with potential to tolerate environmental changes are crucial for surviving at freezing temperatures. Conferring to the qualified advantages and economic returns of strawberry production, it is necessary to identify appropriate cold tolerant cultivars as an advanced content of a given metabolite might associate with higher probabilities of survival before developmental programs. Although several studies report the mechanism of freezing stress tolerance in different plant species, studies on the physiological and biochemical responses of strawberry plants to low temperature stress and associated tolerance mechanisms are lacking. Moreover, the information on genotypic variability among different strawberry cultivars in response to low temperature stress in also lacking. This study was, therefore, conducted to evaluate the physiological and biochemical indicators reflecting the plant responses to freezing stress in different strawberry cultivars and identify the freezing tolerant cultivars. This was hypothesized that strawberry cultivars differ in their responses to low temperature stress.

\section{Results}

The analysis of variance indicates that freezing temperature treatments, cultivars, and the interaction of freezing temperatures and cultivars significantly affected all physiological and biochemical traits (Table 1).

\section{Maximum quantum yield of PSII (Fv/Fm)}

A decrease in the leaf $\mathrm{Fv} / \mathrm{Fm}$ was observed with a decrease in temperature in all tested strawberry cultivars. The highest reduction in $\mathrm{Fv} / \mathrm{Fm}$ was observed in the cultivars Tennessee Beauty and Chandler under freezing stress, especially at $-15^{\circ} \mathrm{C}$ to $-25^{\circ} \mathrm{C}$ (Fig. 1). The Fv/Fm was decreased up to 50 and $41 \%$ in cultivars Tennessee Beauty and Chandler compared to the controls, respectively (Fig. 1).

\section{Leaf relative water contents (RWC)}

The leaf relative water contents decreased significantly by low temperature treatment in all tested strawberry cultivars. However, the rate of decrease differed among the tested cultivars. The cultivar Tennessee Beauty had the RWC value of $75.8 \%$ at $+4{ }^{\circ} \mathrm{C}$, the lowest value at this temperature. At $-25^{\circ} \mathrm{C}$, the cultivar Tennessee Beauty had the highest RWC of $61.24 \%$ compared to the lowest value of $38.5 \%$ in the cultivar Kurdistan. The highest RWC was noted in the cultivar Yalova at $+4{ }^{\circ} \mathrm{C}$ compared to the other cultivars, while the lowest value was observed in the cultivar Kurdistan at $-25^{\circ} \mathrm{C}$ (Fig. 2). The rate of reduction of RWC content in the cultivars Queen Elisa, Krasnyy Bereg, and Kurdistan under freezing temperatures was higher than that of the cultivars Chandler, Tennessee Beauty, and Blackmore (Fig. 2).

\section{Freezing injury (FI)}

The rate of freezing injury (FI) in the crown and leaf tissues increased with a decrease in temperature in all tested strawberry cultivars (Fig. 3; Fig. S1). At $-15^{\circ} \mathrm{C}$, a significant increase in crown FI was observed in the cultivar Blakmore compared to the other cultivars (Fig. 3a). However, the highest FI was observed in the cultivar Yalova followed by the cultivars Chandler and Tennessee Beauty with decreasing the temperature to $-25^{\circ} \mathrm{C}$. The range of differences between cultivars in terms of crown FI was higher at $-25^{\circ} \mathrm{C}$ than other freezing temperatures. Therefore, the cultivars were divided into two groups: the first group had cultivars Krasnyy Bereg, Queen Elisa, and Kurdistan with a low 
Table 1 Analysis of variance for the influence of freezing temperature stress on physiological, biochemical, and morphological traits of strawberry cultivars

\begin{tabular}{|c|c|c|c|c|c|c|c|c|c|}
\hline \multirow[b]{2}{*}{$\begin{array}{l}\text { Source of vari- } \\
\text { ance }\end{array}$} & \multirow[b]{2}{*}{ df } & \multicolumn{8}{|c|}{ Mean sum of squares } \\
\hline & & $F_{v} / F_{m}$ & RWC & Leaf FI & Crown Fl & $\begin{array}{l}\text { Leaf total solu- } \\
\text { ble carbohy- } \\
\text { drates }\end{array}$ & $\begin{array}{l}\text { Crown total } \\
\text { soluble carbo- } \\
\text { hydrates }\end{array}$ & $\begin{array}{l}\text { Crown total } \\
\text { protein }\end{array}$ & Leaf total protein \\
\hline $\begin{array}{l}\text { Temperature } \\
\text { (T) }\end{array}$ & 5 & $0.24^{* *}$ & $2672.32^{* *}$ & $7033.60^{* *}$ & $13,085.56^{* *}$ & $1559.10^{* *}$ & $1169.19^{* *}$ & $605.43^{* *}$ & $1017.92^{* *}$ \\
\hline Cultivar (C) & 6 & $0.041^{* *}$ & $156.07^{* *}$ & $841.38^{* *}$ & $281.68^{* *}$ & $96.99^{* *}$ & $124.54^{* *}$ & $44.83^{* *}$ & $101.13^{* *}$ \\
\hline $\mathrm{T} \times \mathrm{C}$ & 30 & $0.006^{* *}$ & $62.93^{* *}$ & $180.20^{* *}$ & $183.5^{* *}$ & $13.38^{* *}$ & $20.47^{* *}$ & $35.56^{* *}$ & $21.99^{* *}$ \\
\hline Error & 84 & 0.0001 & 10.66 & 3.07 & 0.97 & 2.79 & 0.34 & 1.43 & 0.64 \\
\hline \multirow{2}{*}{$\begin{array}{l}\text { Coefficient of } \\
\text { variation (\%) }\end{array}$} & & 2.79 & 4.78 & 9.73 & 4.69 & 3.94 & 3.27 & 7.81 & 4.27 \\
\hline & & \multicolumn{8}{|c|}{ Mean sum of squares } \\
\hline $\begin{array}{l}\text { Source of vari- } \\
\text { ance }\end{array}$ & $d f$ & Leaf proline & Crown proline & Leaf TBARS & Crown TBARS & Leaf SOD & Crown SOD & Leaf POD & Crown POD \\
\hline $\begin{array}{l}\text { Temperature } \\
\text { (T) }\end{array}$ & 5 & $18.39^{* *}$ & $21.99^{* *}$ & $515.82^{* *}$ & $513.90^{* *}$ & $1637.38^{* *}$ & $238.45^{* *}$ & $98.37^{* *}$ & $1076.53^{* *}$ \\
\hline Cultivar (C) & 6 & $2.57^{* *}$ & $2.57^{* *}$ & $28.75^{* *}$ & $40.25^{* *}$ & $240.07^{* *}$ & $33.86^{* *}$ & $73.49^{* *}$ & $219.16^{* *}$ \\
\hline $\mathrm{T} \times \mathrm{C}$ & 30 & $1.85^{* *}$ & $1.16^{* *}$ & $7.53^{* *}$ & $8.86^{* *}$ & $134.98^{* *}$ & $81.88^{* *}$ & $76.19^{* *}$ & $166.13^{* *}$ \\
\hline Error & 84 & 0.02 & 0.009 & 0.61 & 0.56 & 1.17 & 0.87 & 2.49 & 3.07 \\
\hline $\begin{array}{l}\text { Coefficient of } \\
\text { variation (\%) }\end{array}$ & & 9.35 & 5.93 & 6.35 & 6.41 & 8.77 & 10.19 & 13.23 & 16.67 \\
\hline
\end{tabular}

$d f$ Degree of freedom, Fv/Fm Maximum quantum yield of PSII, RWC Leaf relative water content, FI Freezing injury, TBARS Thiobarbituric acid reactive substances, SOD Superoxide dismutase, $P O D$ Peroxidase

** Significant at $P \leq 0.05$

rate of FI, and the cultivars Yalova, Chandler, Tennessee Beauty, and Blackmore with high crown FI were placed in the second group (Fig. 3a). Leaf FI in all cultivars was zero at $+4^{\circ} \mathrm{C}$, while an increase in FI was noticed with decrease in the temperature (Fig. 3b). With a decrease in the temperature to $-15^{\circ} \mathrm{C}$, a significant increase in FI was noted in the cultivars Chandler, Tennessee Beauty, and Blackmore compared to other cultivars. The cultivars Krasnyy Bereg, Queen Elisa, and Kurdistan had the lowest leaf $\mathrm{FI}$ at $-15^{\circ} \mathrm{C}$ (between 8 to $12 \%$ ). However, the relative FI remained between 53 to $65 \%$ in the other four cultivars (Fig. 3b).

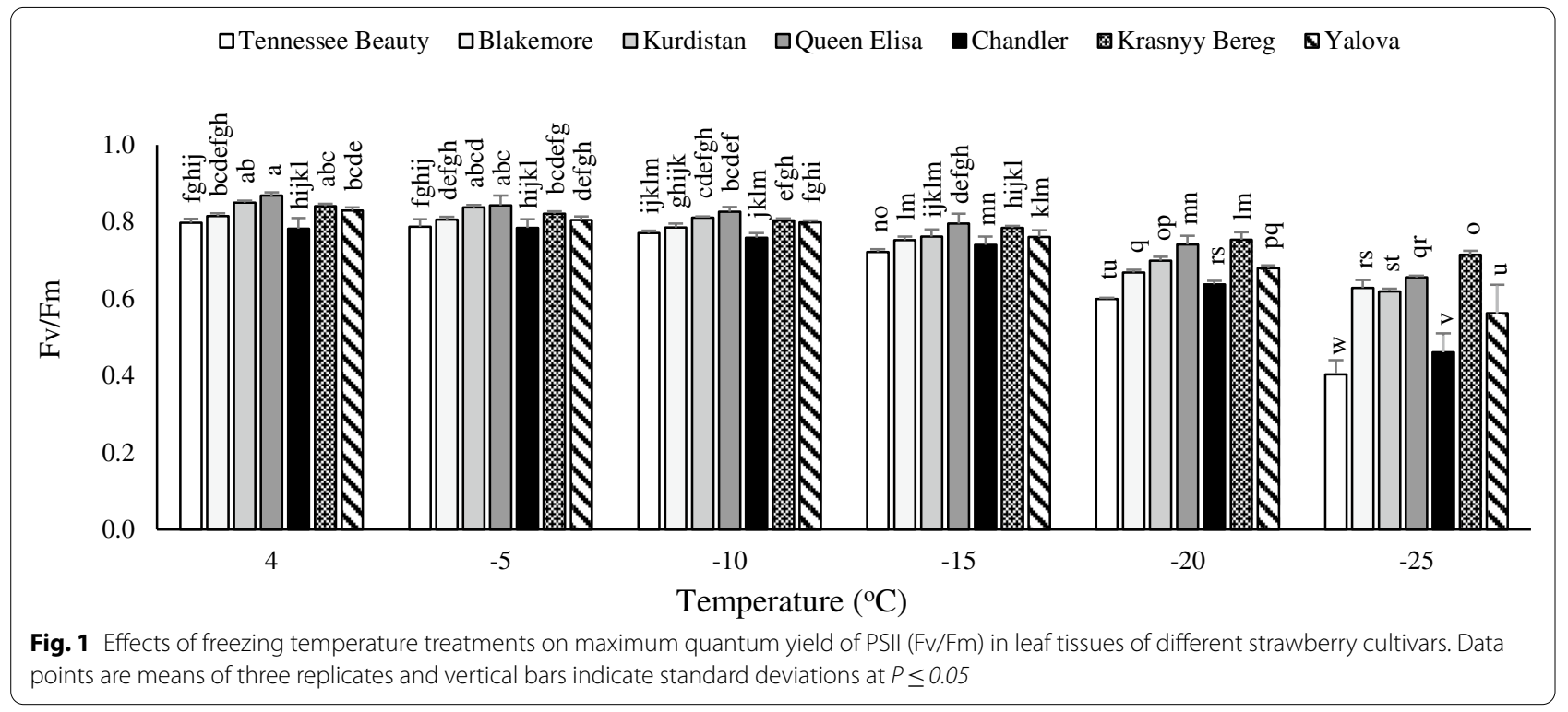




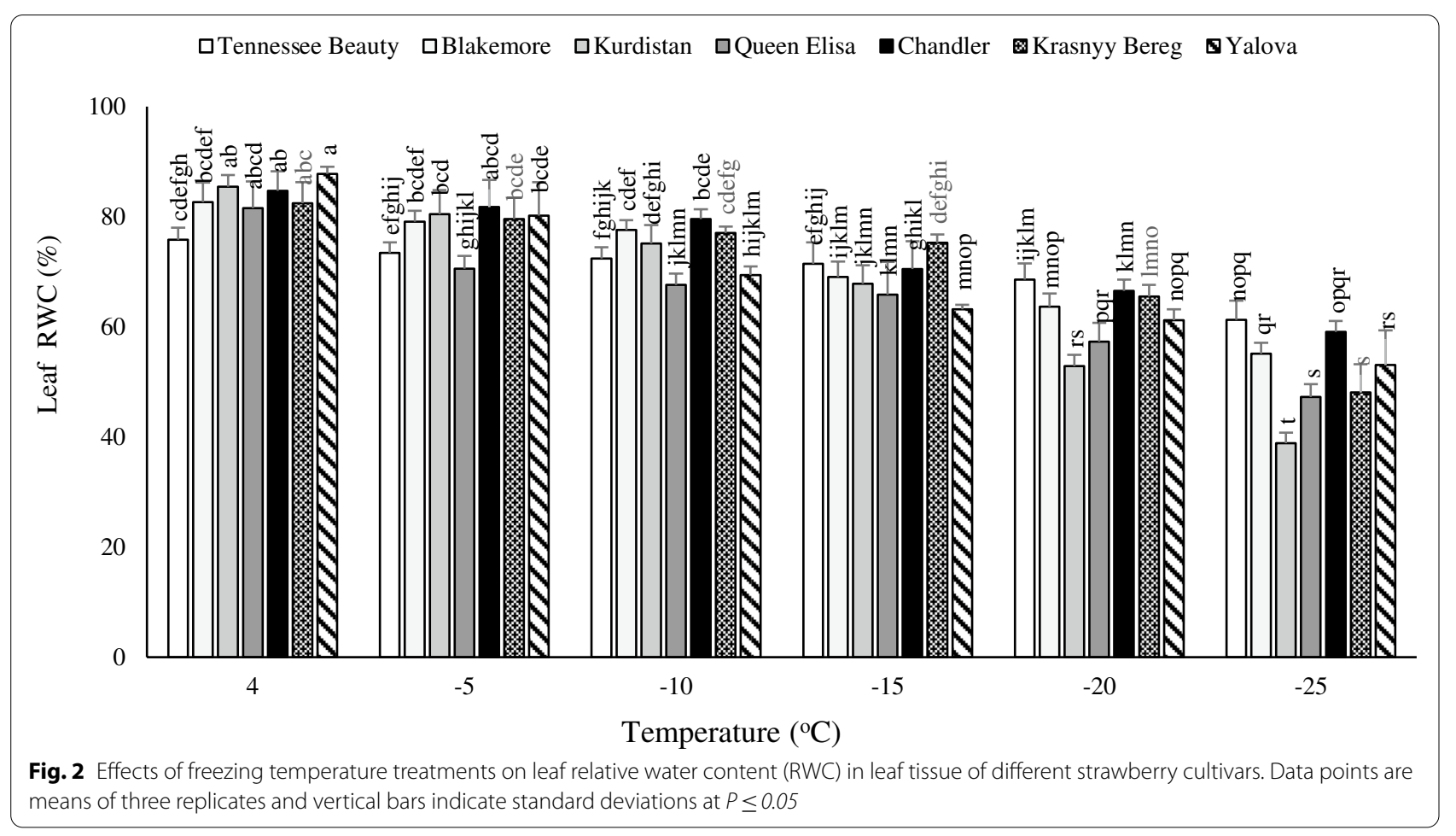

\section{Total soluble carbohydrates}

Before the imposition of freezing temperature treatments (at $+4{ }^{\circ} \mathrm{C}$ ), crowns of cultivars Queen Elisa and Krasnyy Bereg showed the highest amount of total soluble carbohydrates compared to other cultivars. The highest crown soluble carbohydrates contents were recorded in the cultivar Kurdistan at -5 to $-15^{\circ} \mathrm{C}$, while the cultivar Blackmore had the highest total soluble carbohydrates at temperatures -20 to $-25^{\circ} \mathrm{C}$. The cultivar Tennessee Beauty had the lowest carbohydrates contents at the most temperature ranges (Fig. 4a). The cultivar Kurdistan had the highest leaf carbohydrates contents compared to other cultivars at $+4{ }^{\circ} \mathrm{C}$. Between -5 to $-20^{\circ} \mathrm{C}$, the highest leaf carbohydrate contents were noted in the cultivar Yalova. At $-25^{\circ} \mathrm{C}$, the cultivars Krasnyy Bereg and Tennessee Beauty had the highest and lowest leaf carbohydrates contents, respectively (Fig. 4b). The response of strawberry plants to freezing temperature showed a significant difference in terms of leaf carbohydrates. In contrast to other cultivars, the cultivar Krasnyy Bereg maintained an upward trend up to $-25^{\circ} \mathrm{C}$. As temperature decreased from -20 to $-25^{\circ} \mathrm{C}$, a rapid and significant increase in the soluble carbohydrates was noted in this cultivar. However, in other cultivars, the maximum level of soluble carbohydrates was detected in the temperature range from -15 to $-20^{\circ} \mathrm{C}$. However, a reduction in these values was noted with a decrease in temperature (Fig. 4b).

\section{Total soluble protein}

A decrease in temperature to $-5^{\circ} \mathrm{C}$ caused a significant increase in the total soluble protein of crown tissue in all tested cultivars (Fig. 5). Then, up to $-15^{\circ} \mathrm{C}$, a decreasing trend was observed in the soluble protein. At $-20^{\circ} \mathrm{C}$, a rapid increment in the crown soluble protein was noted in all tested strawberry cultivars. However, this increase at $-20^{\circ} \mathrm{C}$ temperature was much higher in sensitive cultivars including Tennessee Beauty and Chandler (Fig. 5a). Although, the total protein peak in crowns was observed in the sensitive and tolerant cultivars at -20 and $-5^{\circ} \mathrm{C}$, respectively (Fig. 5a), sensitive cultivars including Tennessee Beauty and Chandler had the highest total soluble protein contents in the crown tissue compared to other cultivars at $-20^{\circ} \mathrm{C}$, respectively. While the lowest total soluble protein contents were noted in the tolerant cultivar Krasnyy Bereg at $-25^{\circ} \mathrm{C}$. The highest leaf soluble protein contents were observed in the cultivar Tennessee Beauty at $-15^{\circ} \mathrm{C}$ (Fig. 5b). In general, the sensitive cultivar Tennessee Beauty had the highest leaf total protein in comparison with other cultivars at the temperature range of -5 to $-20^{\circ} \mathrm{C}$. However, the least changes were observed in Krasnyy Bereg in contrast to the other tested 


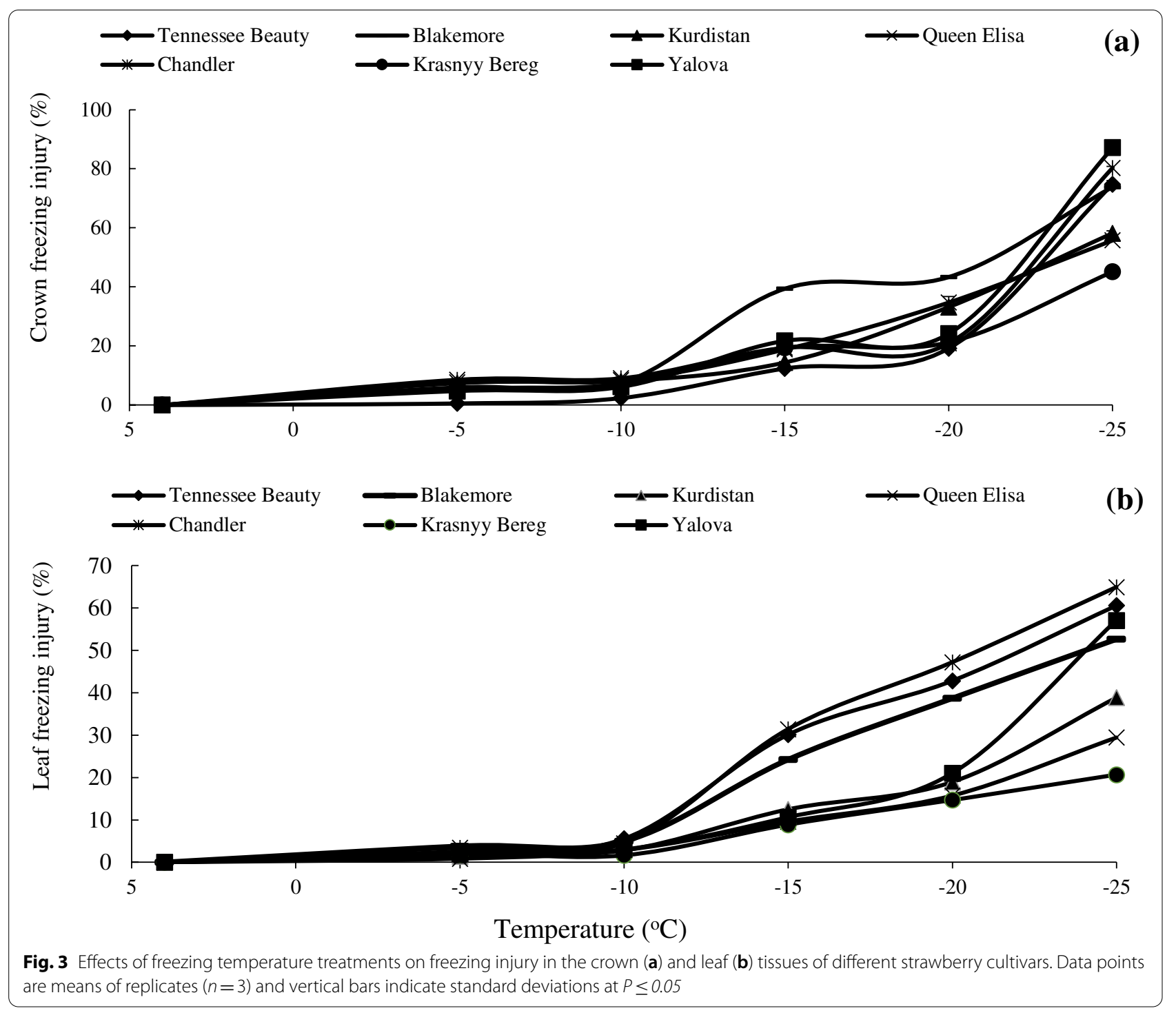

cultivars. In this cultivar, no decreasing trend of soluble proteins was noted at the temperature range of -20 to $-25^{\circ} \mathrm{C}$ (Fig. 5).

\section{Proline content}

A significant increase in the crown proline was noted in the cultivar Tennessee Beauty than other cultivars with the temperature decrease to $-10^{\circ} \mathrm{C}$. The highest crown proline was noted at $-15^{\circ} \mathrm{C}$ and $-20^{\circ} \mathrm{C}$ for the cultivar Blakemore (Fig. 6). A decreasing trend in crown proline content was observed in all tested cultivars at $-25^{\circ} \mathrm{C}$ (Fig. 6a). With a decrease in temperature, an increase in leaf proline content was noted in all tested strawberry cultivars. Although, the highest proline contents in the tested cultivars were noted at different temperatures (Fig. 6b), the highest leaf proline contents in cultivars Tennessee Beauty and Chandler were noted at $-15^{\circ} \mathrm{C}$ (earlier than other tested cultivars) due to more sensitivity to the low temperatures. The highest leaf proline contents were observed in the cultivars Blakemore, Kurdistan, Krasnyy Bereg, and Yalova at $-20^{\circ} \mathrm{C}$, and Queen Elisa at $-25^{\circ} \mathrm{C}$ (Fig. 6b).

\section{TBARS content}

The freezing temperature, to $-25^{\circ} \mathrm{C}$, caused a significant increase in the content of TBARS. In this regard, the lowest TBARS value was noted in the crown of cultivars Krasnyy Bereg and Kurdistan at $-25^{\circ} \mathrm{C}$ (Fig. 7a). The highest and lowest increments were observed in the cultivars Queen Elisa and Krasnyy Bereg by 4.82 and 2.78 fold, respectively. The trend of changes in the TBARS content of crown in strawberry cultivars under freezing temperature treatments was similar to that in the 


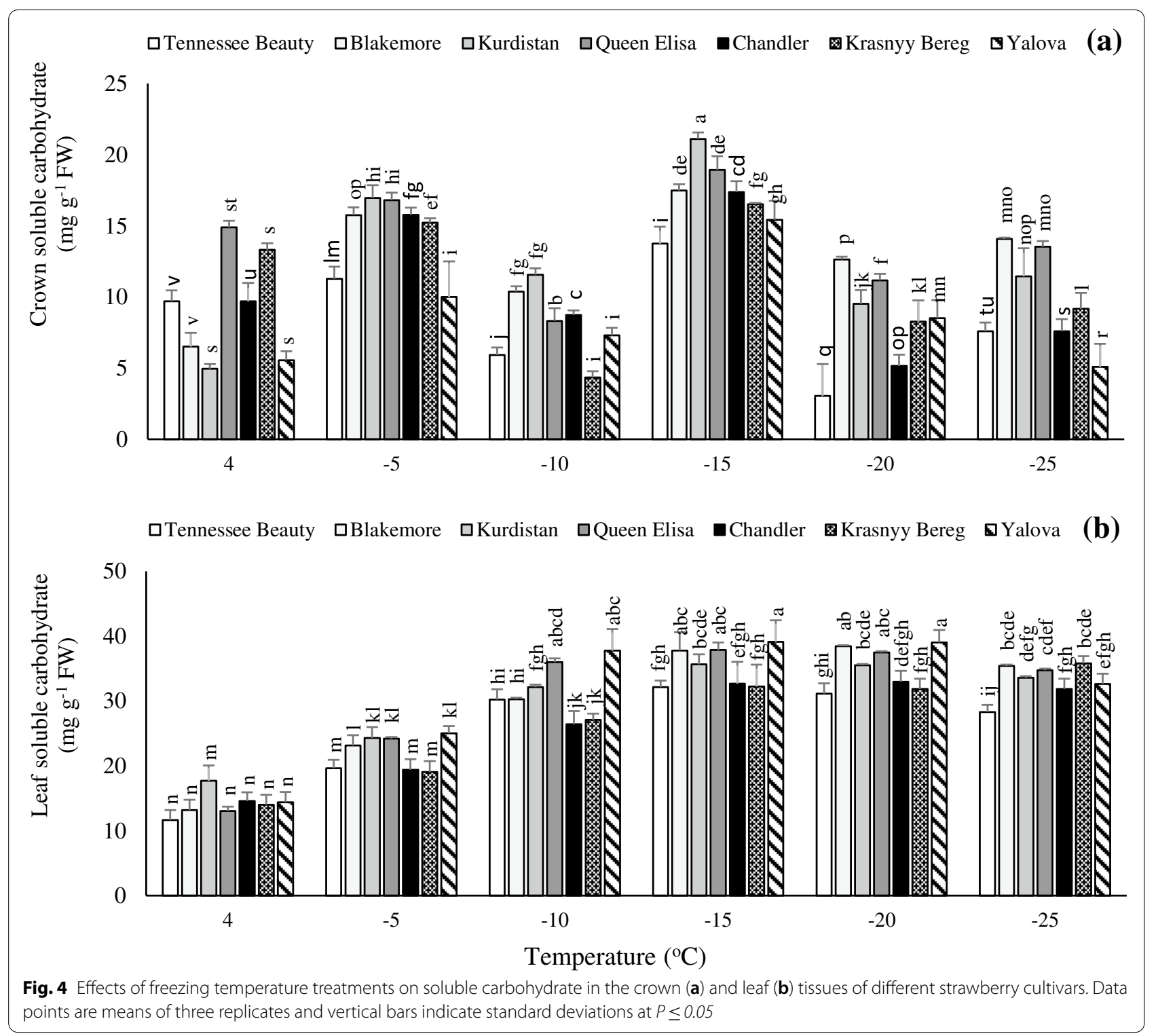

leaves except in cultivar Tennessee Beauty. At $-25^{\circ} \mathrm{C}$, the highest leaf TBARS contents were observed in the cultivar Yalova followed by cultivar Chandler. However, the lowest value was detected in the cultivar Queen Elisa at $-25^{\circ} \mathrm{C}$ (Fig. $7 \mathrm{~b}$ ). At temperatures below $-15^{\circ} \mathrm{C}$, the leaf TBARS content in the cultivars Yalova and Chandler showed a significant increase compared to tolerant cultivars Krasnyy Bereg and Queen Elisa (Fig. 7b).

\section{Activities of antioxidant enzymes}

Freezing temperature treatments caused an overall increase in the SOD activity. However, variations in the crown SOD activity were different from that of leaf tissue. The increase of SOD activity in the crown occurred slightly late and the peak of its activity in most cultivars was noted at $-15^{\circ} \mathrm{C}$ (Fig. 8a). The highest crown SOD activity was observed in tolerant cultivars Queen Elisa and Kurdistan. An increase in the leaf SOD activities was noted with a decrease in temperature in all the tested cultivars (Fig. 8b). The SOD activity was increased at $+4{ }^{\circ} \mathrm{C}$ and then gradually decreased with a decrease in the temperature. The highest leaf SOD activity was noted in the cultivars Krasnyy Bereg and Queen Elisa.

The crown tissue showed a faster response to POD activity in tolerant cultivars than the leaves. The secondary peak of POD activity was observed at $-15^{\circ} \mathrm{C}$ in the 


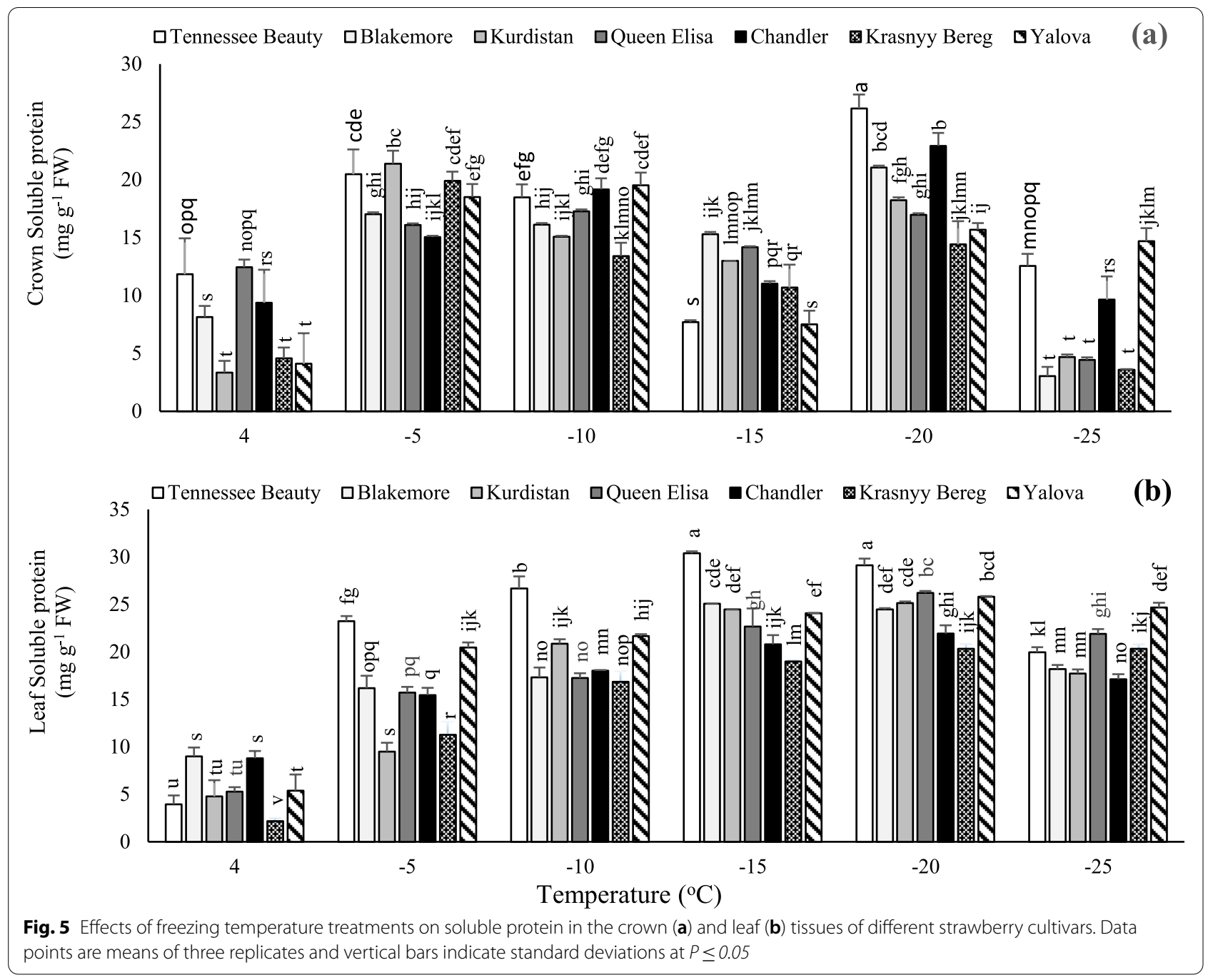

cultivars Krasnyy Bereg, Queen Elisa, Kurdistan, and Yalova (Fig. 9a).

\section{Correlation and PCA analyses}

Strong positive correlations were observed between the examined physiological and biochemical traits (Fig. 10a). There was a highly positive correlation between leaf FI and crown FI $(r=0.883)$. Leaf protein, crown proline, and leaf proline had a highly positive correlation with leaf carbohydrates. Leaf protein showed a high correlation with leaf proline $(r=0.716)$. On the other side, TBARS (in crown and leaf) had a strong positive correlation with crown FI $(r=0.816$, $0.871)$ and leaf FI $(r=0.893,0.909)$. Also, leaf TBARS showed a very high positive correlation with TBARS in the crown $(r=0.9)$.

Four principal components were accounted for $97.37 \%$ of the data variability (Table 2 ). The results of PCA indicated that $\mathrm{PC} 1$, the first principal component was accounted for $51.57 \%$ of total variation which exhibited significant positive correlations with leaf RWC, Fv/Fm, crown and leaf FI, crown and leaf TBARS. The first component was regarded as physiological and biochemical traits. $\mathrm{PC} 2$, the second principal component accounted for $74.37 \%$ of the total variation, SOD and POD in both leaf and crown tissues had higher Eigenvectors. The second component represents the contribution of enzymatic activity-related traits (Fig. 10b and c).

\section{Discussion}

The results of the study supported the hypothesis as the tested strawberry cultivars significantly differed in their responses to low temperature stress. This variability and associated tolerance mechanism will help devise the programs to improve cold tolerance in different strawberry genotypes and improve its productivity in the temperature regions in particular. 


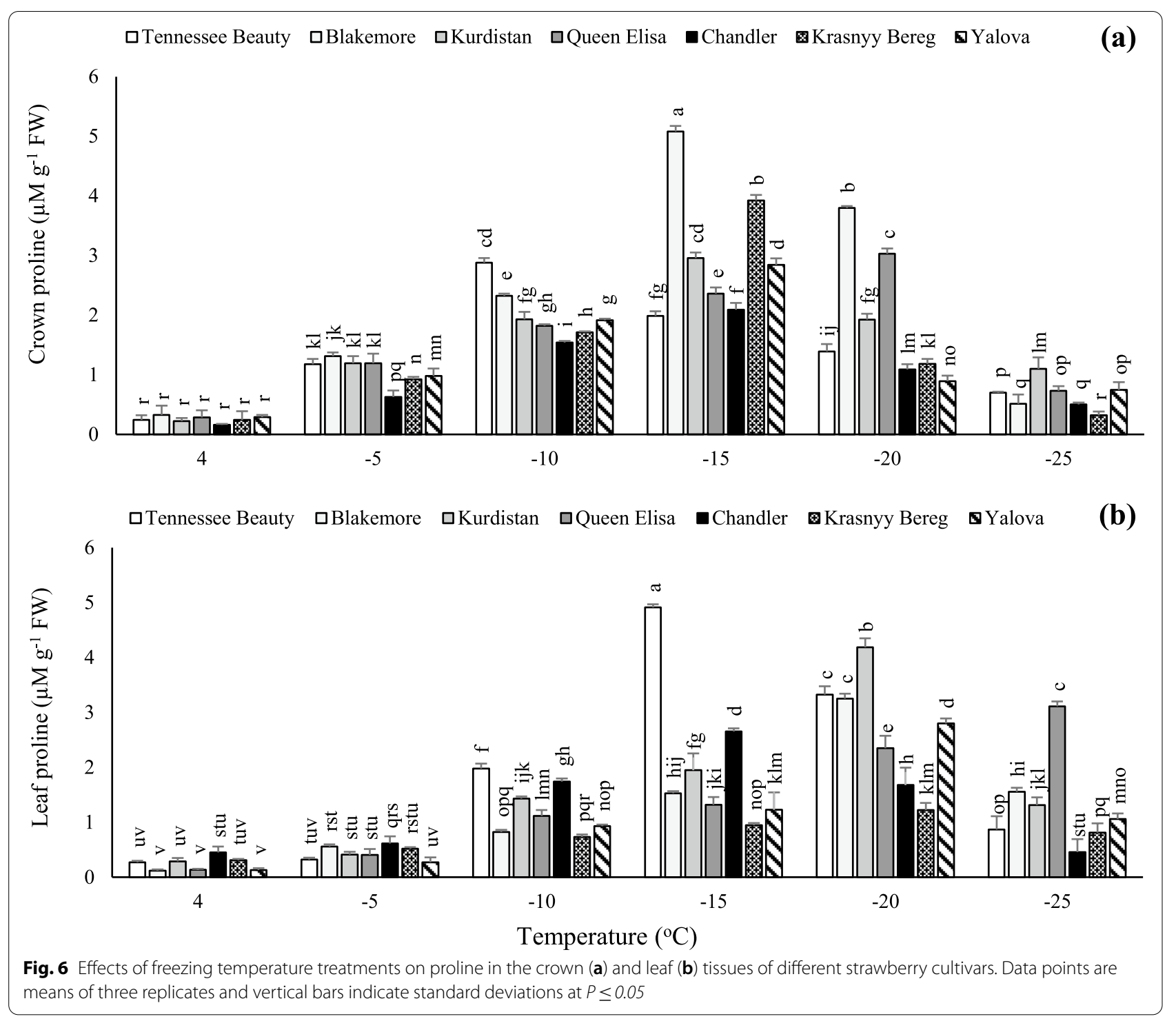

The Freezing temperature tolerance of plant species is indirectly assessed by detecting their photosynthetic activity. Photosynthesis is a key plant metabolic process that is extremely sensitive to low temperature stress. There is evidence that the low temperature may disrupt the key components of photosynthesis [17]. The Fv/Fm ratio is an indicator of the maximum PSII photochemical efficiency and it can be used to examine the activity of PSII [18]. The low temperature induced membrane damage causes reduction in the PSII efficiency of sensitive cultivars. In this study, the observed reduction in $\mathrm{Fv} / \mathrm{Fm}$ may be attributed to damage to the oxygen-evolving apparatus [19] and impairment of electron transfer within the PSII reaction resulting in PSII downstream under freezing temperature. The Fv/
Fm remains in the range of 0.79 to 0.84 for many plant species, with a lowered value indicating plant stress condition [20]. In the healthy leaves, the value of $\mathrm{Fv} /$ Fm value remains closed to 0.8 , independently of the studied plant species [20]. The lower value indicates that a proportion of PSII reaction centers are damaged due to a phenomenon called photo-inhibition often observed in plants under stress conditions. In this study, significant damage on the leaf at $-25^{\circ} \mathrm{C}(\mathrm{Fv} / \mathrm{Fm}$ range from 0.4 to 0.71 ) appears to cause loss or stop of the PSII efficiency resulting in a significant decrease of $\mathrm{Fv} / \mathrm{Fm}$. There were obvious differences in the freezing induced decrease in $\mathrm{Fv} / \mathrm{Fm}$ value between strawberry cultivars, ranging from a decrease by $50 \%$ in the cultivar Tennessee Beauty (freezing sensitive cultivar) to a 


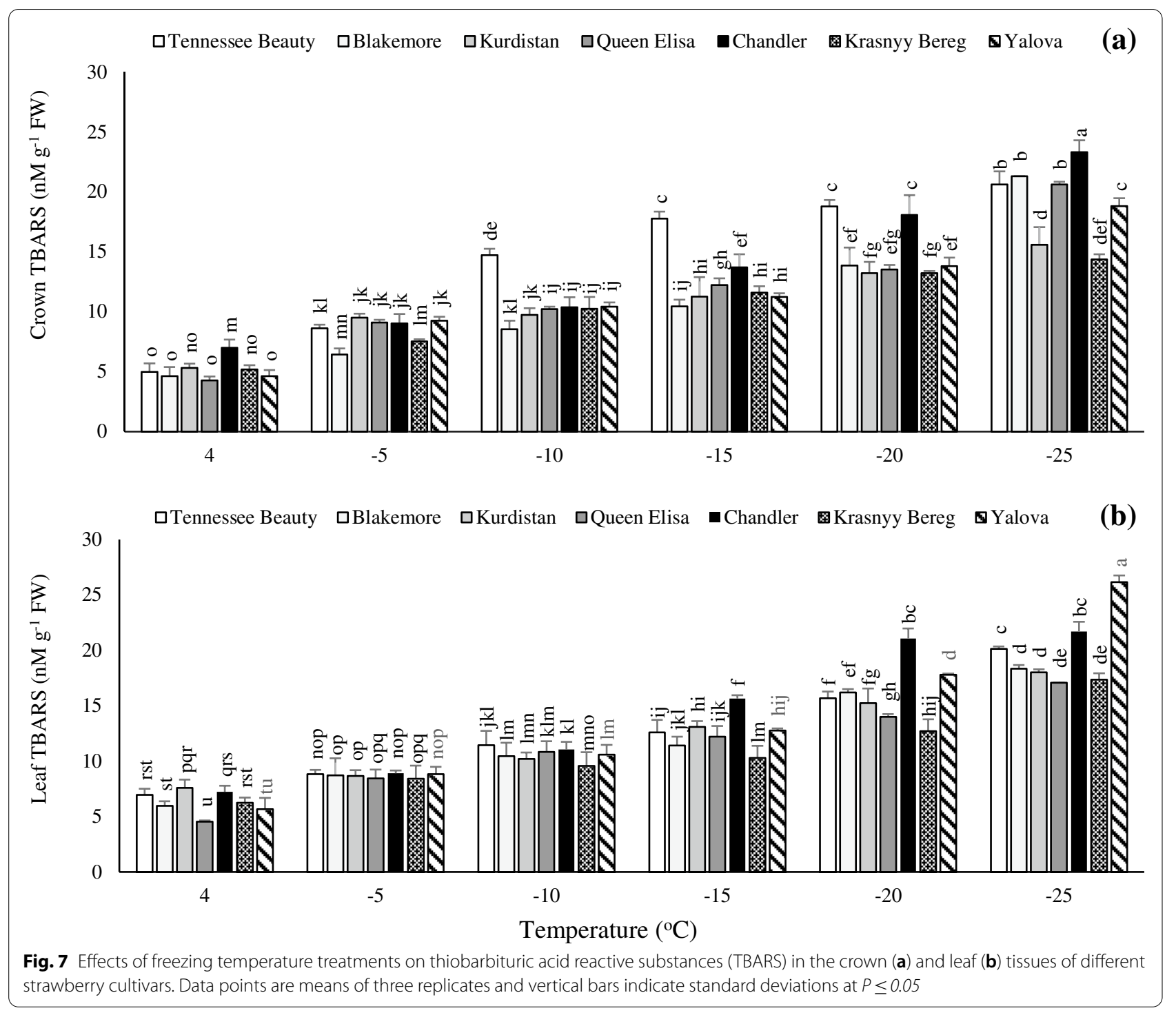

decrease of $15 \%$ in the cultivar Krasnyy Bereg (freezing tolerant cultivar). The $\mathrm{Fv} / \mathrm{Fm}$ values detected from plants under different regimes of light and temperature reached from 0.79 to 0.84 [21]. Choi et al. [21] reported that $\mathrm{Fv} / \mathrm{Fm}$ values is lower in strawberry leaves under both, low temperature $\left(5^{\circ} \mathrm{C}\right)$ and low light conditions. In another study, Makaraci and Flore [22] stated that Chandler and Honeoye cultivars had lower values of $\mathrm{Fv} / \mathrm{Fm}(0.772$ and 0.806$)$ than control (0.833) under $-2{ }^{\circ} \mathrm{C}$ temperature. Our observational evaluations showed that some leaves remained partially healthy in the center of the plant at $-25^{\circ} \mathrm{C}$, although the number of healthy leaves was higher in freezing-tolerant cultivars. In this study, the variable fluorescence reduction was not significant in freezing-tolerant cultivars, while a significant decrease was observed in freezing-sensitive cultivars.
The relative reduction in the tissue water contents is a part of the cold acclimation process and is crucial to freeze tolerance in strawberry plants [23]. Tissue dehydration during the cold acclimatization phase has been observed in many herbaceous plants as well as in various tree species [24]. Under the freezing stress, ice formation is generally initiated in the apoplastic spaces of the extra-cellular fluid which results in the movement of unfrozen water down the chemical potential gradient from inside the cell to the apoplastic space causing cellular dehydration and osmotic contraction of the cell [25]. In this study, leaf RWC was observed to follow a decreasing trend with a decrease in temperature which may be due to low temperature-induced osmotic stress. Upon exposure to cold stress, strawberry plants, like other plant species, experience low temperatures and as well low-temperature-induced drought stress [23]. Freezing 


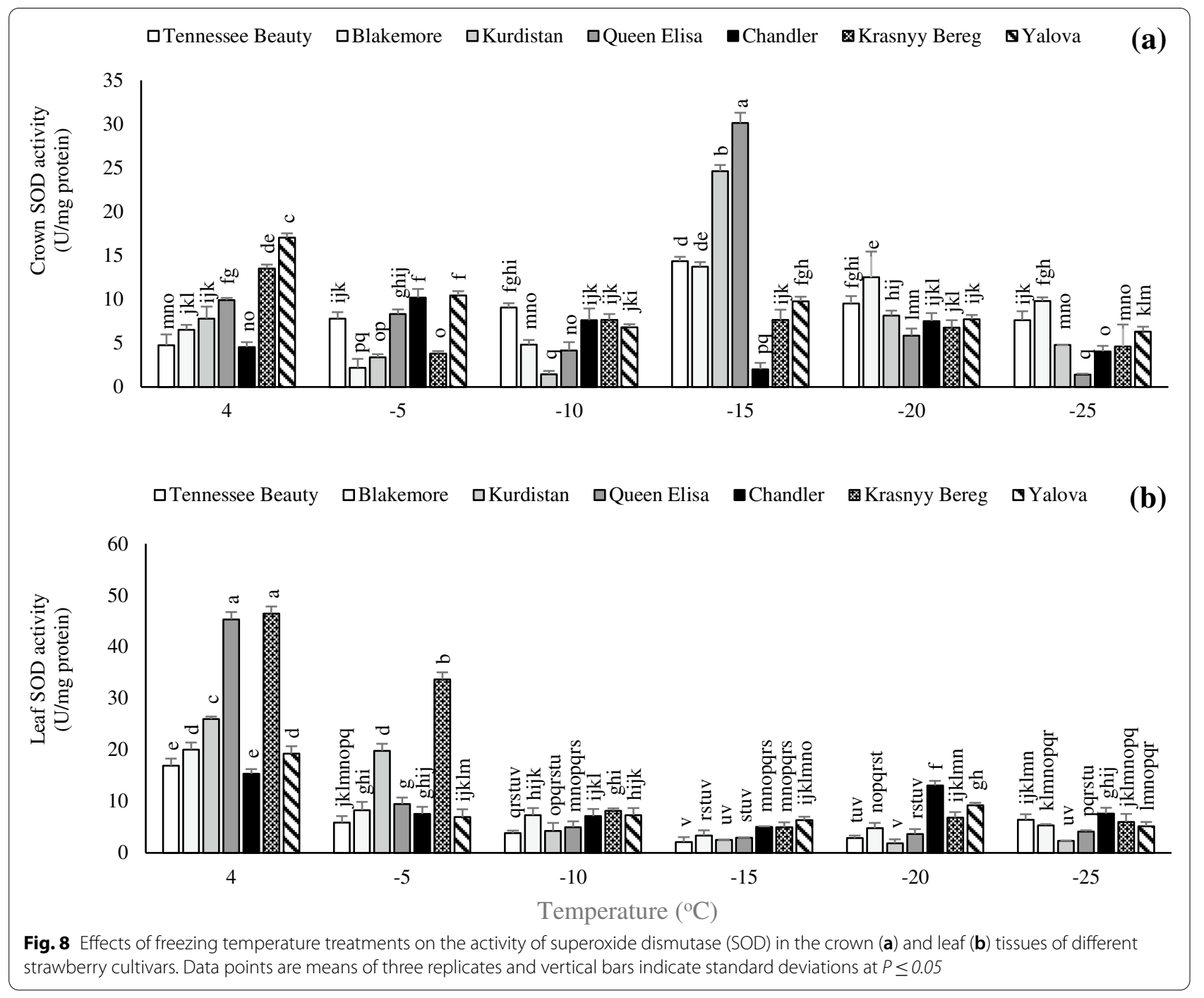

first causes the formation of ice crystals in the plant vessels and then these crystals quickly reach all parts of the plant and penetrate the intercellular areas. These processes cause a difference in osmotic pressure outside and within the cells and lead to water leakage and severe plasmolysis of cells. This study indicates that the more severe decrease of leaf water, under freezing temperature, in tolerant cultivars may be closely linked with the openings of the stomata and preserving the possibility of entry of $\mathrm{CO}_{2}$ and is associated with the elimination of the stomata resistance in photosynthesis. The results of this experiment also demonstrated that tolerant cultivars are more capable to decrease rapidly the RWC. The low relative RWC in tolerant cultivars under low temperatures can also be due to the breakdown of large molecules such as polysaccharides and the production of simpler sugars which increases the osmotic potential and decreases the relative water contents $[26,27]$.
The lower FI in the tolerant cultivars may be due to the greater stability of the physical and chemical properties of the cell plasma membrane in both crown and leaf tissues of strawberry cultivars. The results of this study indicate that crown tissue displayed the lower FI than the leaf FI. The crown is especially sensitive to ice crystal-induced damages due to the large cells of the pith tissue. As described earlier by Campos et al. [28], cell membranes are likely to be the first areas to be affected by freezing damage. Low temperature stress reduces the fluidity of the membrane which in addition to lipid peroxidation, destroys the membrane and thus increases ion leakage. The degree of leaf damage is correlated with the damage to the plasma membrane of mesophilic cells [29]. The greatest damage is caused by intracellular freezing stress. However, Pearce [30], reported that the formed extracellular ice in both freezing tolerant and sensitive species may lead to cellular dehydration. However, 


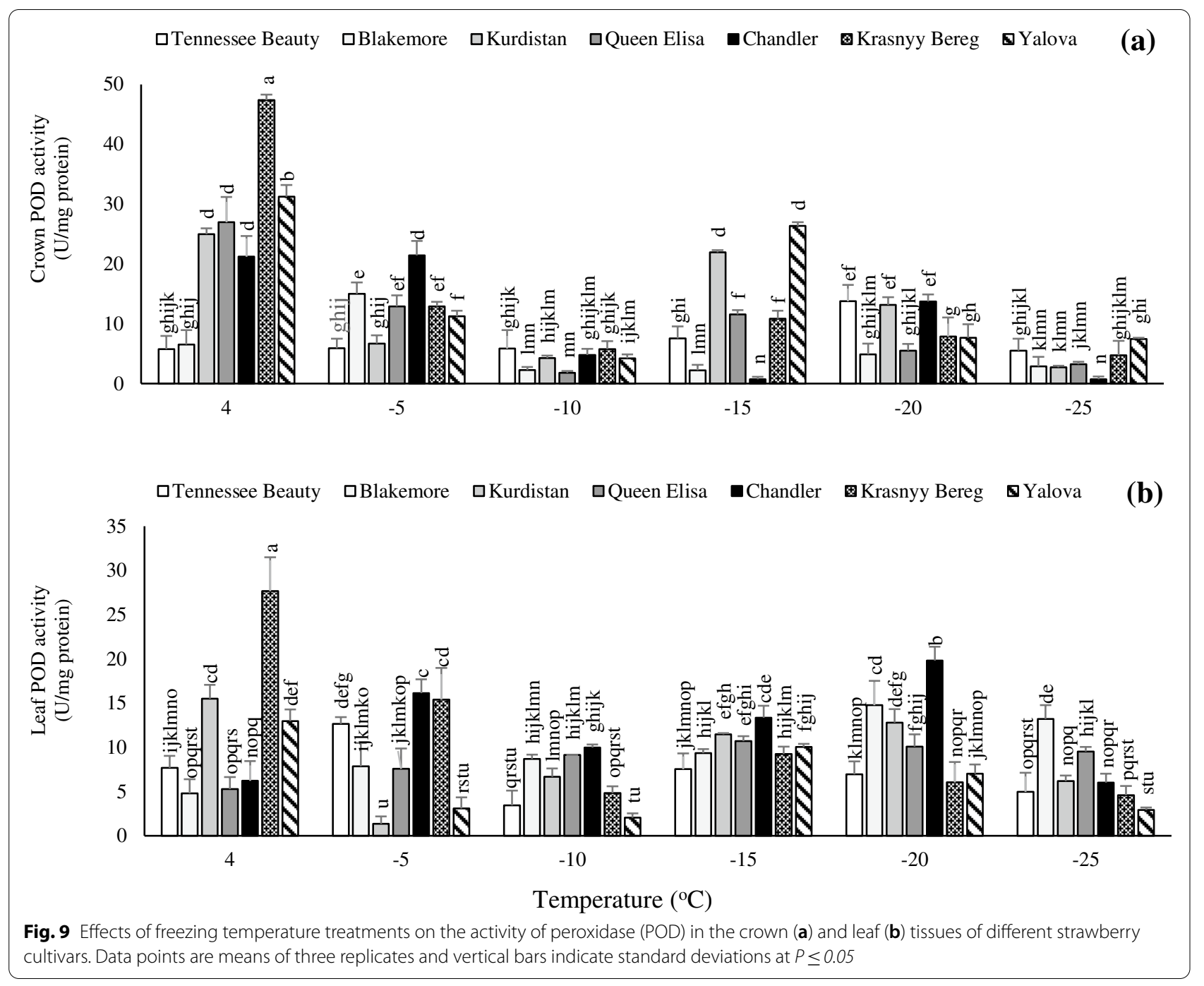

freezing damage happens when the high dehydration is too much for the cells to tolerate. In this context, Azzarello et al. [31] indicated that freezing stress enhanced the membrane degradation of olive seedlings consequently that increased the ion leakage. Low temperature provokes an imbalance in photolysis resulting in an over-reduction of electron transport chain in thylakoid membranes and generation of reactive oxygen species (ROS) in PSI (photosystem I) and PSII [32, 33]. The production of ROS during the low temperature exposure also leads to lipid peroxidation resulting in ion leakage. Lipid peroxidation is a free radical-mediated degradation process that involves in homolysis of polyunsaturated fatty acids subsequent to the formation of lipid radicals.

In all tested cultivars, the trend of changes in the crown was different from the ones in the leaf in terms of soluble carbohydrates contents (Fig. 4). Significant variations in the soluble carbohydrates in the crown of strawberry cultivars indicate the sensitivity level of this tissue under freezing stress as well as the increased metabolic activity related to the transfer and consumption of carbohydrates and associated mechanisms involved in freezing temperature tolerance. The response of the tested cultivars to freezing temperatures was completely different in terms of leaf soluble carbohydrates changes. The cultivars Krasnyy Bereg, Queen Elisa, and Kurdistan cultivars showed more tolerance to low temperatures by having higher soluble carbohydrates content compared to other cultivars at $-25^{\circ} \mathrm{C}$. However, the upper levels of soluble carbohydrates in the tolerant cultivars may correspond to that of sensitive cultivars in some other plant species [11, 34-36]. The accumulation of various metabolites such as carbohydrates, in strawberry plants, is one of the known features of cold adaptation [11]. Soluble solids collaborate in increasing the osmotic potential and continuously decreasing the cytoplasmic freezing point [37]. 


\begin{tabular}{|l|l|l|l|}
\hline \multicolumn{1}{|c|}{ (a) } & \\
& \\
leaf RWC \\
fv/fm \\
crown FI \\
leaf FI \\
crown carbohydrates \\
leaf carbohydrates \\
crown protein \\
leaf protein \\
crown proline \\
leaf proline \\
crown TBARS \\
leaf TBRAS \\
crown SOD \\
leaf SOD \\
crown POD \\
leaf POD
\end{tabular}
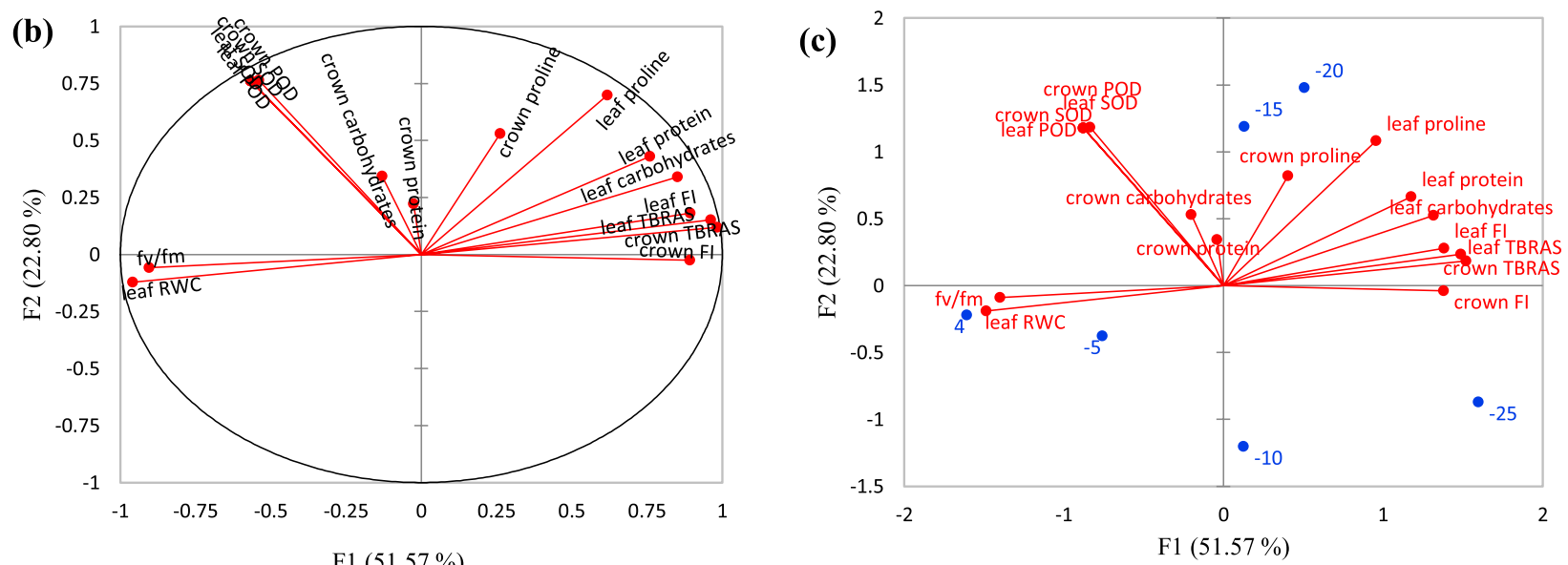

F1 $(51.57 \%)$

Fig. 10 The correlation matrix between the different physiological and biochemical traits (a), principal component analysis (PCA) related to observations (b), and biplot (c) in strawberry cultivars under freezing temperature stress

Soluble sugars are involved in the crystallization process which protects plants from freezing damage [38]. Carbohydrates are elaborated in the formation of ice crystals in the intercellular space and reduction of the mechanical damage associated with freezing. When the temperature

Table 2 Eigenvalue, variability, and cumulative variance percentage for the four factors resulted from principal component analysis (PCA)

\begin{tabular}{lllll}
\hline & PC1 & PC2 & PC3 & PC4 \\
\hline Eigenvalue & 8.25 & 3.65 & 2.58 & 1.09 \\
Variability (\%) & 51.57 & 22.8 & 16.15 & 6.85 \\
Cumulative \% & 51.57 & 74.37 & 90.52 & 97.37
\end{tabular}

$P C 1$ the first principal component, $P C 2$ the second principal component, $P C 3$ the third principal component and $P C 4$ the fourth principal component drops, the water freezes in the intercellular space, and the intracellular water is drawn from the cells to the intercellular ice mass. Cells of freezing tolerant organs accumulate low molecular weight carbohydrates and proline to prevent the dehydration of intracellular water [39]. Low temperature stimulates the expression of genes that encode the enzymes required for the biosynthesis of these compounds [37]. The cultivar Krasnyy Bereg had less changes in total soluble protein than other cultivars at temperatures $-20^{\circ} \mathrm{C}$. This indicates that there was no significant damage in this cultivar in the terms of protein degradation and reduction. While a sharp decrease was observed in total soluble protein in Tennessee Beauty cultivar at the temperature range of -20 to $-25^{\circ} \mathrm{C}$. In all strawberry cultivars, the fluctuations of the total soluble proteins in the crown were more than the leaves, 
indicating more sensitiveness of the crown against freezing temperature. In general, the amount of crown soluble proteins was the same as the leaf amounts in sensitive cultivars, although the trend of changes in the crown was more severe and different. Crown tissue as the center of strawberry growth plays a key role in the metabolic activities related to the transportation and consumption of soluble proteins involved in freezing temperature tolerance. Increasing the content of soluble protein and carbohydrates is one of the properties of acclimation to cold stress and plays a major role in reducing freezinginduced damage in plant tissues. So that with decreasing temperature, the amount of protein often increases $[36,40]$. Proteomic findings confirm that freezing tolerant proteins such as dehydrins and lipocalins accumulate in plasma membranes when plant exposure to low temperatures, although their action is unclear exactly. In this regard, Ouellet and Charron [37] demonstrated that these proteins protect molecules and cell structures from freezing damage and reduce the development of oxidative stress. Lukoševičiūtè et al. [11] also stated that the content of $18 \mathrm{kDa}$ protein significantly increased during the cold adaptation process in the shoots in two strawberry cultivars.

The decrease in temperature also caused an overall increase in the amount of proline in both crown and leaf in all cultivars. The trend of changes of proline content in crown tissue was similar to changes in leaf. While the sensitiveness level of the crowns to freezing temperatures was higher than leaves. In addition, the peak of proline content happened faster in the crown tissue. The enhanced levels of proline accumulation in plants exposed to numerous abiotic stresses have been reported in various plant species $[41,42]$. The present findings are consistent with other studies which found that proline has also been proposed as a non-water electron donor to PSII during abiotic stress conditions in plants besides playing the ROS-scavenger role [41, 43]. The increased proline accumulation in freezing sensitive strawberry cultivars indicates that these plants demonstrate the requirement of proline in the integrity of the cellular system for survival under stress conditions. The higher proline content and total soluble carbohydrates can be correlated with the ability of the strawberry plants to survive the freeze damage. According to Linden et al. [44], under low temperature conditions, the accumulation of soluble carbohydrates in winter wheat of the tolerant cultivar "Lina" was higher than the sensitive cultivar "Apollo", while the amount of proline accumulated was higher in sensitive cultivars. Based on our results, the accumulation of soluble carbohydrates in the tolerant cultivars including Krasnyy Bereg, Queen Elisa, and Kurdistan was higher than sensitive cultivars such as Tennessee Beauty and Chandler under freezing temperatures, while its peak occurred faster in sensitive cultivars. Temperature below $-20^{\circ} \mathrm{C}$ caused a significant decrement in proline accumulation of sensitive cultivars.

Determination of TBARS is often used as an indicator of the degree of peroxidation of membrane lipids and the level of plant sensitiveness to oxidative damage [45]. Overproduction of ROS has a detrimental effect on cell growth and development causing the peroxidation of membrane lipids and the production of toxic species such as TBARS, which leads to cell dysfunction and death $[46,47]$. The reduction of unsaturated fatty acids leads to loss of fluidity and selective permeability of the membrane resulting in the reduced cold resistance [48]. According to the current results, the content of TBARS in leaves was generally higher in the tolerant cultivars. Reports showed that low temperature stress at different times led to an increment in malondialdehyde content in strawberry cultivars [49]. The present results are consistent with Palonen et al. [50] and Ershadi et al. [34] who showed that decreasing temperature often results in increasing the content of soluble carbohydrates and malondialdehyde.

In freezing-sensitive cultivars such as Tennessee Beauty and Chandler, the secondary peak of POD activity was observed by a delay at $-20^{\circ} \mathrm{C}$ that represents a faster response of tolerant cultivars to accumulation of ROS for preventing oxidative stress injury under freezing temperatures. The leaf POD activity showed a considerable enhancement, especially in the tolerant cultivar Krasnyy Bereg than the other cultivars. Dissimilar to the SOD activity, POD activity showed a second peak at $-20^{\circ} \mathrm{C}$ after the early peak at $+4^{\circ} \mathrm{C}$ in all cultivars (Fig. 9b). Guo et al. [51] have been stated that there is a correlation between antioxidant enzyme activity and plant tolerance to abiotic stresses such as low temperature stress, so that plants with higher levels of antioxidants are more tolerant to oxidative damage. Luo et al. [52] observed that the activity of SOD rapidly increased at the beginning of cold treatment and then gradually decreased in two strawberry cultivars. Also, they observed that the POD showed a rapid enhancement at the onset of freezing treatment and then a steady upward trend during the freezing period, although a slight decrement was observed in one of them in the middle of the period. The higher activity of SOD in barley and rice cold tolerant cultivars than cold sensitive cultivars have been reported [53].

\section{Conclusions}

In the present study, freezing stress was characterized by decreased Fv/Fm and RWC, and increased FI, TBARS, total carbohydrates, total proteins, proline content, and antioxidant enzyme activity. The extent of changes in 
abovementioned traits was cultivar dependent. According to the results, FI and TBARS were the best traits among destructive parameters for evaluating freezing tolerance. Moreover, maximum quantum yield of PSII ( $\mathrm{Fv} / \mathrm{Fm}$ index), as non-destructive parameters, showed a significant efficiency in rapid assessment for screening of freezing tolerant strawberry cultivars. Strawberry cultivar Krasnyy Bereg was the most tolerant to freezing temperatures compared to other cultivars, the cultivars Queen Elisa and Kurdistan were ranked next to it. These cultivars may be recommended for cultivation in regions with very low winter temperatures. In contrast to the other sensitive cultivars, the cultivar Yalova had good tolerance to freezing temperatures up to $-20^{\circ} \mathrm{C}$, but with decreasing the temperature to $-25^{\circ} \mathrm{C}$, the freezing damage increased significantly in this cultivar. The freezing-tolerant cultivars (Kurdistan, Queen Elisa, and Krasnyy Bereg) showed less level of freezing injury suggesting a higher tissues survival percentage.

Chlorophyll fluorescence measurement, as an easy and non-destructive field technique, had a significant efficiency in rapid assessment of invisible damages and maximum quantum yield of PSII (Fv/Fm index) was the best indicator compared to other methods for screening of freezing-tolerant genotypes. The cultivars with a high level of tolerance to freezing temperature can be used as a parent in breeding programs to produce the new cultivars.

\section{Methods}

\section{Growth conditions and temperature treatments}

Bare-root daughters of seven strawberry cultivars (Fragaria $\times$ ananassa Dutch.) with uniform crown diameter $(10 \mathrm{~mm})$ were provided by the Kurdistan Agricultural and Natural Resources Research and Education Center, AREEO, Kurdistan, Iran. Experimental research and field studies on strawberry cultivars complied with Iran and Kurdistan province local legislation. The breeding parents and geographical origin of the tested cultivars (Tennessee Beauty, Blakemore, Kurdistan, Queen Elisa, Chandler, Krasnyy Bereg, and Yalova) are given in Table 3. Strawberry plants were grown in pots filled with perlite, vermicompost, and coco peat $(60: 30: 10)$ and were maintained outdoor during March-October in 2019 until the imposition of freezing temperature treatments. Monthly weather conditions of the experimental site are given in Table 4. The plants were exposed to the natural low temperatures of autumn for cold acclimation. For the imposition of freezing temperature treatments, the potted plants were exposed to the temperature of +4 (as control) $,-5,-10,-15,-20$, and $-25^{\circ} \mathrm{C}$ by a programmable thermogradient refrigeration chamber (Thermogradient cooling chamber made by Kimia Rahavard Company, Iran) equipped with halogen lightbulb and the light intensity of $\approx 300 \mu \mathrm{mol} \mathrm{m}^{-2} \mathrm{~s}^{-1}$ was maintained during the light period of $12 \mathrm{~h}$ and $70 \pm 5 \%$ relative humidity. Before the imposition of freezing temperature treatments, leaves of strawberries were thoroughly washed with distilled water to remove surface contaminants and were allowed to dry naturally to avoid water residue (later ice) formation on their surface. Temperature treatments were applied based on the average ambient temperature and considering the process of acclimatization of plants to freezing and adapting to natural conditions as much as possible as follows: $+4^{\circ} \mathrm{C}$ (October 30$),-5^{\circ} \mathrm{C}$ (November 20), $-10^{\circ} \mathrm{C}$ (December 4$),-15^{\circ} \mathrm{C}$ (December 20), $-20^{\circ} \mathrm{C}$ (January 15), and $-25^{\circ} \mathrm{C}$ (January 30). The process of gradual decrease of temperature continued at a rate of $2^{\circ} \mathrm{C}$ /hour until the target temperature was reached (for example, $-20^{\circ} \mathrm{C}$ ). The samples were then exposed to the target temperatures for $75 \mathrm{~min}$. Afterward, the temperature was gradually increased again (at a rate of $2^{\circ} \mathrm{C} /$ hour), until the temperature $+4^{\circ} \mathrm{C}$ was reached. Four strawberry plants of each cultivar (one plant in each pot) per three replicates were evaluated in each experimental unit. Three individual crowns and leaves were taken from plants for further analyses. For chlorophyll fluorescence assessment, the samples were selected 1 week after the imposition of temperature treatments to precisely assess the damage to the green tissue.

\section{Biochemical and physiological parameters Maximum quantum yield of PSII (Fv/Fm)}

Three middle mature leaves, from each pot, were selected and chlorophyll fluorescence was measured by a portable chlorophyll fluorometer (OS-30P, OptiSciences Inc., USA). The measurement was done after the plants were dark-adapted for $20 \mathrm{~min}$. The maximum quantum efficiency of Photosystem II (PSII) primary photochemistry $(\mathrm{Fv} / \mathrm{Fm})$ was calculated following Miralles-Crespo et al. [54].

Table 3 The breeding parents and origin of strawberry cultivars used in the study

\begin{tabular}{lll}
\hline Cultivar & Breeding parents & Origin \\
\hline Tennessee Beauty & Howard $17 \times$ Missionary & USA \\
Blakemore & Missionary $\times$ Howard 17 & USA \\
Kurdistan $^{\text {a }}$ & Unknown & Unknown \\
Queen Elisa & Miss. $\times$ Usb 35 & Italy \\
Chandler & Douglas $\times$ Cal 72-361-105 & USA \\
Krasnyy Bereg & Venta $\times$ Tenira & Belarus \\
Yalova & Arnavutkoy $\times$ Aliso & Turkey \\
\hline
\end{tabular}

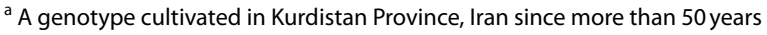


Table 4 The weather data of the experimental site during the course of the investigation

\begin{tabular}{|c|c|c|c|c|c|c|c|}
\hline Month & $\begin{array}{l}\text { Average min } \\
\text { temp. }\left({ }^{\circ} \mathrm{C}\right)\end{array}$ & $\begin{array}{l}\text { Average max } \\
\text { temp. }\left({ }^{\circ} \mathrm{C}\right)\end{array}$ & Mean temp. $\left({ }^{\circ} \mathrm{C}\right)$ & $\begin{array}{l}\text { Average relative } \\
\text { humidity (\%) }\end{array}$ & $\begin{array}{l}\text { Average min } \\
\text { humidity (\%) }\end{array}$ & $\begin{array}{l}\text { Average max } \\
\text { humidity (\%) }\end{array}$ & $\begin{array}{l}\text { Total } \\
\text { precipitation } \\
(\mathrm{mm})\end{array}$ \\
\hline Apr & 3.60 & 18.7 & 11.2 & 55.0 & 28.9 & 81.1 & 39.6 \\
\hline May & 7.90 & 27.4 & 17.7 & 38.2 & 13.6 & 62.7 & 7.80 \\
\hline Jun & 13.1 & 34.4 & 23.8 & 27.4 & 9.70 & 45.2 & 0.00 \\
\hline Jul & 18.7 & 39.2 & 28.9 & 22.0 & 8.40 & 35.6 & 2.00 \\
\hline Aug & 18.2 & 39.6 & 28.9 & 19.3 & 6.80 & 31.8 & 0.00 \\
\hline Sep & 14.3 & 33.8 & 24.1 & 33.4 & 12.6 & 54.2 & 5.50 \\
\hline Oct & 9.60 & 28.7 & 19.1 & 36.5 & 15.7 & 57.4 & 1.10 \\
\hline Nov & 4.50 & 15.7 & 10.1 & 69.5 & 48.1 & 90.9 & 206.4 \\
\hline Dec & -1.4 & 8.40 & 3.50 & 70.1 & 51.3 & 88.9 & 40.6 \\
\hline Jan & -2.2 & 8.50 & 3.20 & 65.9 & 46.1 & 85.7 & 29.6 \\
\hline Feb & -2.9 & 9.80 & 3.50 & 62.6 & 38.8 & 86.5 & 56.9 \\
\hline Mar & 3.00 & 16.6 & 9.80 & 55.3 & 30.8 & 79.9 & 40.8 \\
\hline
\end{tabular}

\section{Leaf relative water content ( $R W C$ )}

Leaf relative water content (RWC) were determined from five randomly selected fully developed leaves. The RWC was calculated using the following equation (Eq. 1):

$$
\mathrm{RWC}=(\mathrm{FW}-\mathrm{DW}) /(\mathrm{TW}-\mathrm{DW}) \times 100
$$

Where FW, DW, and TW refer to fresh weight, dry weight, and turgid weight of leaf, respectively.

\section{Freezing injury (FI)}

Three samples of the crown and leaf tissues were put into tubes containing distilled water. The tubes were placed on a shaker at $120 \times g$ for $24 \mathrm{~h}$ at room temperature. The initial electrical conductivity (EC) was measured by an electrical conductivity meter for tissues placed at $+4{ }^{\circ} \mathrm{C}$ for $5 \mathrm{~h}$. Final electrical conductivity was measured after autoclaving at $120^{\circ} \mathrm{C}$ for $30 \mathrm{~min}$, followed by incubation at room temperature for $20 \mathrm{~h}$. Percent of injury was calculated based on [55] as following equation (Eq. 2):

$$
\operatorname{Injury}(\%)=\left(\% \mathrm{EL}\left(\begin{array}{cc}
{ }_{\mathrm{T}}^{\circ} & \mathrm{C}
\end{array}\right)-\% \mathrm{EL}\left(\begin{array}{cc}
\circ & \circ \\
4 & \mathrm{C}
\end{array}\right)\right) /\left(100-\% \mathrm{EL}\left(\begin{array}{cc}
{ }^{\circ} & \mathrm{C}
\end{array}\right)\right) \times 100
$$

Where \% EL $\left(\mathrm{T}_{\mathrm{T}}^{\circ} \mathrm{C}\right)$ and \% EL $\left(4{ }^{\circ} \mathrm{C}\right)$ are the percent of electrolyte leakage (EL) values based on initial electrical conductivity over total electrical conductivity for each freeze target temperature $\left(\mathrm{T}^{\circ} \mathrm{C}\right)$ and unfrozen control $\left(4^{\circ} \mathrm{C}\right)$, respectively. The injury data were transformed using a method proposed by Lim et al. [56].
Total soluble carbohydrates and total soluble protein

The total soluble carbohydrates in the crown and leaf tissues were estimated by a spectrophotometer (SPECORD model 210, Analytik Jena, Germany) as described by Yemm and Willis [57]. The total soluble protein was measured in the crown and leaf tissues according to Bradford method [58].

\section{Proline and TBARS contents}

The proline content in the crown and leaf tissues was determined according to Bates et al. [59]. The TBARS (ThioBarbituric Acid Reactive Substances) contents were examined based on the formation of thiobarbituric acid complex formed by malondialdehyde (MDA) complex [60].

\section{Antioxidant enzyme activities}

The activity of superoxide dismutase (SOD) was determined by measuring its ability to prevent optical reduction of the nitro blue tetrazolium chloride following Beauchamp and Fridovich [61]. The peroxidase (POD) activity was estimated based on the decomposition of $\mathrm{H}_{2} \mathrm{O}_{2}$ into water and oxygen as described by Hemeda and Klein [62].

\section{Statistical analysis}

The experimental data were analyzed by the analysis of variance (ANOVA) using statistical package SAS 9.4 (SAS Institute Inc., ver. 9.1, Cary, NC, USA). For mean separation, Duncan's new multiple range test was used. Computation of Pearson correlation coefficients and principal component analysis (PCA) was done using XLSTAT to investigate the degree of association between the features examined under low temperature stress. 


\section{Abbreviations}

RWC: Relative Water Content; TBARS: ThioBarbituric Acid Reactive Substances; FI: Freezing Injury; SOD: Superoxide Dismutase; POD: Peroxidase.

\section{Supplementary Information}

The online version contains supplementary material available at https://doi. org/10.1186/s12870-021-03300-2.

Additional file 1: Figure S1. Freezing injury in crown and leaf of Yalova cultivar under freezing temperature treatments $\left(-15,-20\right.$, and $\left.-25^{\circ} \mathrm{C}\right)$

\section{Acknowledgements}

We thank the Agricultural and Natural Resources Research and Education Center of Kurdistan Province and Bu Ali Sina University for their financial support. We also thank Dr. Abdolhossein Rezaei Nejad for improving the scientific language of the manuscript.

\section{Authors' contributions}

F.K. and E.Z. conducted field and laboratory investigations and collected data. M. GH. supervised the project. E. Z, F.K., and S.A. performed statistical analysis and produced charts and diagrams. E.Z. and F.K. contributed to writing the manuscript. R.A., G.G., A.E., and M.F. provided critical comments in planning the study and edited the manuscript. All the authors discussed the results and revised the manuscript. The author(s) read and approved the final manuscript.

\section{Funding}

This research did not receive any funding

\section{Availability of data and materials}

The data that support the findings of this study are available from the corresponding author upon reasonable request.

\section{Declarations}

\section{Ethics approval and consent to participate}

We confirm that our study does not involve human subjects.

\section{Consent for publication}

Not applicable.

\section{Competing interests}

The authors declare that they have no competing interests.

\section{Author details}

${ }^{1}$ Department of Horticultural Science, Faculty of Agriculture, University of Tabriz, Tabriz, Iran. ${ }^{2}$ Horticultural Research Department, Kurdistan Agricultural and Natural Resources Research and Education Center, AREEO, Sanandaj, Iran. ${ }^{3}$ Department of Horticultural Sciences, Faculty of Agriculture, Bu-Ali Sina University, Hamedan, Iran. ${ }^{4}$ Department of Horticultural Science, NC State University, Raleigh, NC, USA. ${ }^{5}$ Department of Horticultural Sciences, Faculty of Agriculture, University of Maragheh, Maragheh, Iran. ${ }^{6}$ Department of Plant Sciences, College of Agricultural and Marine Sciences, Sultan Qaboos University, 123 Al-Khoud, Oman.

Received: 31 March 2021 Accepted: 29 October 2021

Published online: 13 November 2021

\section{References}

1. Arora R. Mechanism of freeze-thaw injury and recovery: a cool retrospective and warming up to new ideas. Plant Sci. 2018;270:301-13.

2. Moran RE, Sun Y, Geng F, Zhang D, Fazio G. Cold temperature tolerance of trunk and root tissues in one-or two-year-old apple rootstocks. HortScience. 2011:46:1460-4.
3. Yamazakia T, Kawamura Y, Uemura M. Extracellular freezing-induced mechanical stress and surface area regulation on the plasma membrane in cold-acclimated plant cells. Plant Signal Behav. 2009;4:231-3.

4. Mishra A, Mishra KB, Höermiller II, Heyer AG, Nedbal L. Chlorophyll fluorescence emission as a reporter on cold tolerance in Arabidopsis thaliana accessions. Plant Signal Behav. 2011;6:301-10.

5. Pareek A, Khurana A. K Sharma a, Kumar R. an overview of signaling regulons during cold stress tolerance in plants. Curr Genomics. 2017:18:498-511.

6. Hincha DK. Cryoprotectin: a plant lipid-transfer protein homologue that stabilizes membranes during freezing. Philos Trans R Soc Lond B Biol Sci. 2002;357:909-16.

7. Li S, Yang Y, Zhang Q, Liu N, Xu Q, Hu L. Differential physiological and metabolic response to low temperature in two zoysiagrass genotypes native to high and low latitude. PLoS One. 2018;13:e0198885.

8. Lee JI, Yu DJ, Lee JH, Kim SJ, Lee HJ. Comparison of mid-winter cold-hardiness and soluble sugars contents in the shoots of 21 highbush blueberry (Vaccinium corymbosum) cultivars. J Hortic Sci Biotechnol. 2013;88:727-34

9. Neuner G, Xu B, Hacker J. Velocity and pattern of ice propagation and deep supercooling in woody stems of Castanea sativa, Morus nigra and Quercus robur measured by IDTA. Tree Physiol. 2010;30:1037-45.

10. Khanian M, Marshall N, Zakerhaghighi K, Salimi M, Naghdi A. Transforming agriculture to climate change in Famenin County, West Iran through a focus on environmental, economic and social factors. Weather Climate Extremes. 2018:21:52-64

11. Lukoševičiūtè $V$. Characterization of cold acclimation and cold hardiness of strawberry in vitro and in vivo. PhD Thesis. Aleksandras Stulginskis University; 2014.

12. Palencia P, Martínez F, Medina JJ, López-Medina J. Strawberry yield efficiency and its correlation with temperature and solar radiation. Hortic Bras. 2013:31:93-9.

13. Maibam P, Nawkar GM, Park JH, Sahi VP, Lee SY, Kang CH. The influence of light quality, circadian rhythm, and photoperiod on the CBF-mediated freezing tolerance. Int J Mol Sci. 2013;14:11527-43.

14. Thomashow MF. Molecular basis of plant cold acclimation: insights gained from studying the CBF cold response pathway. Plant Physiol. 2010;154:571-7.

15. Koehler G, Wilson RC, Goodpaster JV, Sønsteby A, Lai X, Witzmann FA, et al. Proteomic study of low-temperature responses in strawberry cultivars (Fragaria $x$ ananassa) that differ in cold tolerance. Plant Physiol. 2012;159:1787-805

16. Warmund MR. Ice distribution inEarliglow'strawberry crowns and tissue recovery following extracellular freezing. J Am Soc Hortic Sci. 1993:118:644-8.

17. Allen DJ, Ort DR. Impacts of chilling temperatures on photosynthesis in warm-climate plants. Trends Plant Sci. 2001:6:36-42.

18. Krause GH, Weis E. Chlorophyll fluorescence and photosynthesis: the basics. Annu Rev Plant Biol. 1991;42:313-49.

19. Enami I, Kitamura M, Tomo T, Isokawa Y, Ohta H, Katoh S. Is the primary cause of thermal inactivation of oxygen evolution in spinach PS II membranes release of the extrinsic $33 \mathrm{kDa}$ protein or of $\mathrm{Mn}$ ? Biochim Biophys Acta (BBA)-Bioenerg. 1994;1186:52-8.

20. Maxwell K, Johnson GN. Chlorophyll fluorescence-a practical guide. J Exp Bot. 2000;51:659-68.

21. Choi HG, Moon BY, Kang NJ. Correlation between strawberry (Fragaria ananassa Duch.) productivity and photosynthesis-related parameters under various growth conditions. Front Plant Sci. 2016;7:1607.

22. Makaraci AZ, Flore JA. The use of chlorophyll fluorescence to determine the effects of different acclimation temperatures on strawberry leaves exposed to mild frost damage. Acta Hortic. 2009;842:813-6.

23. Rajashekar CB, Panda M. Water stress is a component of cold acclimation process essential for inducing full freezing tolerance in strawberry. Sci Hortic. 2014;174:54-9.

24. Lang V, Mantyla E, Welin B, Sundberg B, Palva ET. Alterations in water status, endogenous abscisic acid content, and expression of rab18 gene during the development of freezing tolerance in Arabidopsis thaliana. Plant Physiol. 1994;104:1341-9.

25. Jan N, Andrabi KI. Cold resistance in plants: a mystery unresolved. Electron J Biotechnol. 2009;12:14-5. 
26. Pradhan S, Goswami AK, Singh SK, Prakash J, Goswami S, Chinnusamy $V$, et al. Low temperature stress induced physiological and biochemical alterations in papaya genotypes. S Afr J Bot. 2019;123:133-41.

27. Chang Y, Zhang J, Bao G, Yan B, Qu Y, Zhang M, et al. Physiological responses of highland barley seedlings to $\mathrm{NaCl}$, drought, and freeze-thaw stress. J Plant Growth Regul. 2021;40:154-61.

28. Campos PS, Nia Quartin V, Chicho Ramalho J, Nunes MA. Electrolyte leakage and lipid degradation account for cold sensitivity in leaves of Coffea sp. plants. J Plant Physiol. 2003;160:283-92.

29. Turner JM, Tanino KK, Stushnoff C. Evaluation of low temperature hardiness of strawberry plants under field and controlled conditions. Can J Plant Sci. 1993;73:1123-5.

30. Pearce RS. Plant freezing and damage. Ann Bot. 2001;87:417-24.

31. Azzarello E, Mugnai S, Pandolfi C, Masi E, Marone E, Mancuso S. Comparing image (fractal analysis) and electrochemical (impedance spectroscopy and electrolyte leakage) techniques for the assessment of the freezing tolerance in olive. Trees. 2009;23:159.

32. Ruelland E, Vaultier M-N, Zachowski A, Hurry V. Cold signalling and cold acclimation in plants. Adv Bot Res. 2009;49:35-150.

33. Yun K-Y, Park MR, Mohanty B, Herath V, Xu F, Mauleon R, et al. Transcriptional regulatory network triggered by oxidative signals configures the early response mechanisms of japonica rice to chilling stress. BMC Plant Biol. 2010;10:1-29.

34. Ershadi A, Karimi R, Mahdei KN. Freezing tolerance and its relationship with soluble carbohydrates, proline and water content in 12 grapevine cultivars. Acta Physiol Plant. 2016;38:2.

35. Griffith M, Yaish MW. Antifreeze proteins in overwintering plants: a tale of two activities. Trends Plant Sci. 2004;9:399-405.

36. Kerepesi I, Galiba G. Osmotic and salt stress-induced alteration in soluble carbohydrate content in wheat seedlings. Crop Sci. 2000;40:482-7.

37. Ouellet F, Charron J-B. Cold acclimation and freezing tolerance in plants. In: eLS. Chichester: Wiley; 2013.

38. Gusta LV, Wilen RW, Fu P. Low-temperature stress tolerance: the role of abscisic acid, sugars, and heat-stable proteins. HortScience. 1996;31:39-46.

39. Burg MB, Ferraris JD. Intracellular organic osmolytes: function and regulation. J Biol Chem. 2008;283:7309-13.

40. Vítámvás P, Prášil IT. WCS120 protein family and frost tolerance during cold acclimation, deacclimation and reacclimation of winter wheat. Plant Physiol Biochem. 2008;46:970-6.

41. Ashraf M, Foolad MR. Roles of glycine betaine and proline in improving plant abiotic stress resistance. Environ Exp Bot. 2007:59:206-16.

42. Chinnusamy V, Zhu J, Zhu J-K. Cold stress regulation of gene expression in plants. Trends Plant Sci. 2007;12:444-51.

43. De Ronde JA, Cress WA, Krüger GHJ, Strasser RJ, Van Staden J. Photosynthetic response of transgenic soybean plants, containing an Arabidopsis P5CR gene, during heat and drought stress. J Plant Physiol. 2004;161:1211-24.

44. Lindén L, Seppänen M, Väinölä A, Palonen P. Cold hardiness research on agricultural and horticultural crops in Finland. Agric Food Sci Finland. 1999:8:459-77.

45. Blokhina O, Virolainen E, Fagerstedt KV. Antioxidants, oxidative damage and oxygen deprivation stress: a review. Ann Bot. 2003;91:179-94.
46. Alscher RG, Erturk N, Heath LS. Role of superoxide dismutases (SODs) in controlling oxidative stress in plants. J Exp Bot. 2002;53:1331-41.

47. Zhou B, Guo Z, Liu Z. Effects of abscisic acid on antioxidant systems of Stylosanthes guianensis (Aublet) Sw. Under chilling stress. Crop Sci. 2005;45:599-605.

48. Levitt J. Responses of plants to environmental stresses. Volume II. Water, radiation, salt, and other stresses. New York: Academic Press; 1980. p. 25-211.

49. Yong Z, Hao-Ru T, Ya L. Variation in antioxidant enzyme activities of two strawberry cultivars with short-term low temperature stress. World J Agric Sci. 2008;4:458-62.

50. Palonen P, Buszard D, Donnelly D. Changes in carbohydrates and freezing tolerance during cold acclimation of red raspberry cultivars grown in vitro and in vivo. Physiol Plant. 2000;110:393-401.

51. Guo Z, Ou W, Lu S, Zhong Q. Differential responses of antioxidative system to chilling and drought in four rice cultivars differing in sensitivity. Plant Physiol Biochem. 2006;44:828-36.

52. Luo Y, Tang H, Zhang Y. Production of reactive oxygen species and antioxidant metabolism about strawberry leaves to low temperatures. J Agric Sci. 2011;3:89-96.

53. Fu X-J, Maimaiti AS, Mou H-M, Yang Q, Liu G-J. Hexanoic acid 2-(diethylamino) ethyl ester enhances chilling tolerance in strawberry seedlings by impact on photosynthesis and antioxidants. Biol Plant. 2011;55:793.

54. Miralles-Crespo J, Martínez-López JA, Franco-Leemhuis JA, Banón-Arias S. Determining freezing injury from changes in chlorophyll fluorescence in potted oleander plants. HortScience. 2011;46:895-900.

55. Arora R, Wisniewski ME. Cold acclimation in genetically related (sibling) deciduous and evergreen peach (Prunus persica [L.] Batsch)(II. A 60-kilodalton bark protein in cold-acclimated tissues of peach is heat stable and related to the dehydrin family of proteins). Plant Physiol. 1994;105:95-101.

56. Lim CC, Arora R, Townsend EC. Comparing Gompertz and Richards functions to estimate freezing injury in Rhododendron using electrolyte leakage. J Am Soc Hortic Sci. 1998;123:246-52.

57. Yemm EW, Willis AJ. Stomatal movements and changes of carbohydrate in leaves of Chrysanthemum maximum. New Phytol. 1954;53:373-96.

58. Bradford MM. A rapid and sensitive method for the quantitation of microgram quantities of protein utilizing the principle of protein-dye binding. Anal Biochem. 1976;72:248-54.

59. Bates LS, Waldren RP, Teare ID. Rapid determination of free proline for water-stress studies. Plant Soil. 1973;39:205-7.

60. Heath RL, Packer L. Photoperoxidation in isolated chloroplasts: I. kinetics and stoichiometry of fatty acid peroxidation. Arch Biochem Biophys. 1968;125:189-98.

61. Beauchamp C, Fridovich I. Superoxide dismutase: improved assays and an assay applicable to acrylamide gels. Anal Biochem. 1971;44:276-87.

62. Hemeda HM, Klein BP. Effects of naturally occurring antioxidants on peroxidase activity of vegetable extracts. J Food Sci. 1990;55:184-5.

\section{Publisher's Note}

Springer Nature remains neutral with regard to jurisdictional claims in published maps and institutional affiliations.

Ready to submit your research? Choose BMC and benefit from:

- fast, convenient online submission

- thorough peer review by experienced researchers in your field

- rapid publication on acceptance

- support for research data, including large and complex data types

- gold Open Access which fosters wider collaboration and increased citations

- maximum visibility for your research: over 100M website views per year

At BMC, research is always in progress.

Learn more biomedcentral.com/submissions 